\title{
Point-of-care diagnosis of COVID-19 disease based on antigen tests
}

\author{
Pohanka M \\ Faculty of Military Health Sciences, University of Defense, Hradec Kralove, Czech Republic. \\ miroslav.pohanka@gmail.com
}

\begin{abstract}
AIMS: This review is focused on the laboratory diagnoses of the coronavirus disease 2019 (COVID-19) by recognizing the antigen of the causative agent SARS-CoV-2 virus. Various antigen tests are available in this moment and these tests are being further developed in order to reach a better diagnostic value. The issue is reviewed in a complex view.

METHODS: In this work, a complex survey of the current literature was made. The relevant and recent papers related to antigen tests of COVID-19 are discussed and cited. Basic specifications of the antigen tests and competitive methods were also scrutinized in the current literature.

RESULTS: The survey of the current literature (years 2019 - 2021) was made and diagnostic methods like lateral flow tests (lateral flow immunochromatographic assay) and various types of biosensors were specified as tools for COVID-19 diagnosis and their application to be used as a point-of-care test is considered. CONCLUSIONS: Small hand-held assays applicable in the point-of-care conditions for diagnosis of COVID-19 by analysis of SARS-CoV-2 antigen are the means of a growing interest and these means undergo a significant development leading to the improvements of their specifications and applicability to the current praxis. Merit of the assays is discussed in this paper (Tab. 3, Fig. 2, Ref. 109). Text in PDF www.elis.sk KEY WORDS: coronavirus disease 2019; diagnosis; enzyme-linked immunosorbent assay; immunoassay; lateral flow test; SARS-CoV-2.
\end{abstract}

\section{Introduction}

Since the end of year 2019, the coronavirus disease 2019 (COVID-19 or COVID) has gained a broad attention due to enormous impact on the mankind and the unprecedent urgent biomedical research on protective means, drugs, and vaccines. The means for diagnosis were recognized as an important tool for the control of the epidemy. When the disease was firstly recognized in the Wuhan city in China in the end of 2019, mankind was unprepared and urgent development of new diagnostic tests and drugs became a race with time (1). Since the 2019, the disease turned from a local epidemy to a global pandemic with more than three million of fatal victims and nearly 150 million of infected people. The progression over the population was quite fast due to limited number of vaccines and effective drugs and countries, where the worst scenarios happened are out of their medical capacities dur-

Faculty of Military Health Sciences, University of Defense, Hradec Kralove, Czech Republic

Address for correspondence: M. Pohanka, MD, Faculty of Military Health Sciences, University of Defense, Trebesska 1575, CZ-500 01 Hradec Kralove, Czech Republic.

Acknowledgements: This work was supported by A long-term organization development plan "Medical Aspects of Weapons of Mass Destruction" (Faculty of Military Health Sciences, University of Defense, Czech Republic). ing the most urgent periods of the epidemy and the disease tends to easily disseminate over the word countries (2-5). New drugs, vaccines and therapies has been developed since the disease appearing (6-11).

Early diagnosis of COVID-19 is a crucial step for the epidemiological measures and preventing from spreading of the disease by the isolation of the infected individuals. In the current time, various immunochemical and genetical tests are available in the market and serve for the purpose of early diagnosis (12-14). In this review, point-of-care antigen tests are surveyed as the tool for a simple diagnosis of COVID-19. Important facts about the assays, current literature and discussion of the antigen tests' significance are given in this review. These tests are also compared to the other types of diagnostic means.

\section{The basic facts about COVID-19}

The COVID-19 is an infectious disease caused by the Severe Acute Respiratory Syndrome Coronavirus 2 (SARS-CoV-2). The basic mechanism of SARS-CoV-2 spreading is based on micrometric particles released by coughing and sneezing by the infected people (15-17). As discussed in the text further, the release of viral particles from mucosa is a way how to receive the samples taken e.g. by swabbing from nasopharynx. The viral particles penetrate into host cells by the interaction with angiotensin-converting enzyme 2 (ACE2) on the host cells surface $(18,19)$. Under normal 
Tab. 1. The common specifications of COVID 19 and SARS-CoV-2.

\begin{tabular}{ll}
\hline Specification & Description \\
\hline Pathogen & Severe Acute Respiratory Syndrome Coronavirus 2 (SARS-CoV-2) \\
\hline Disease & coronavirus disease 2019 (COVID-19 or COVID) \\
\hline Major symptoms & breathlessness, fatigue, fever and cough \\
\hline Other symptoms & loss of smell (ansomia), dyspnea, loss of taste, depression, anxiety, hypercoagulability, acute ischemia stroke \\
\hline Approximate size and weight of a virion & $100 \mathrm{~nm} / 1 \mathrm{fg}$ \\
\hline Genetic information of the virus & positive-sense single stranded RNA \\
\hline Notable proteins & envelope (E), nucleocapsid (N), membrane (M), and spike (S) proteins \\
\hline
\end{tabular}

conditions, the ACE2 is responsible for the negative regulation of the renin-angiotensin system and facilitation of amino acid transport in the lungs, nasal mucosa, cardiovascular system, gut, kidneys, nervous system and adipose tissue $(20,21)$. Just these tissues can be targeted by SARS-CoV-2 because of the receptor system presence on their cells. Based on the SARS-CoV-2 impact on the tissues, many visual symptoms can be observed and used for the purpose of differential diagnosis. Breathlessness, fatigue, fever and cough can be mentioned as the most common symptoms $(22,23)$. Neurological symptoms like a loss of smell (ansomia), dyspnea, and loss of taste can be also manifested though a delay of some days after the main symptoms can be expected (24-26). Other neurological symptoms like depression and anxiety symptoms can occur as well (27). In the patients with COVID-19 or post disease recovery, there were also observed: hypercoagulability, stroke associated with cardioembolic mechanism, focal cerebral arteriopathy and acute ischemia stroke $(28,29)$.

SARS-CoV-2 is an enveloped virus having virion particles with approximate diameter $100 \mathrm{~nm}$ and weight $1 \mathrm{fg}$, containing positive-sense single stranded RNA inside the particle and also containing the envelope protein (E), nucleocapsid (also known as nucleoprotein) protein $(\mathrm{N})$, membrane protein $(\mathrm{M})$, and spike protein (S) (30). The E protein plays a role in the control of life cycle, envelope formation and pathogenesis (31). The $\mathrm{N}$ protein participates in RNA package and spreading (32). The M protein interacts with $\mathrm{S}, \mathrm{E}$ and $\mathrm{N}$ proteins and it is a protein with a sugar transporter-like structure having structural and stabilizing function though its role has not been fully studied yet (33). The S protein is the most abundant molecule of SARS-CoV-2 virion particle and make it a substantial target for immune system or a marker for analysis. In the virus life cycle, the $\mathrm{S}$ protein is responsible for the interaction with ACE2, for which it exerts specificity and further penetration into cells (34-36). The common specifications of COVID-19 respective SARS-CoV-2 are surveyed in Table 1.

The common antigen tests and comparison with the other methods

The fact that SARS-CoV-2 virion particles contains structures giving a rise of specific antibodies also gives the opportunity to use a manufactured antibody for the purpose of COVID-19 diagnosis. Two basic approaches exist in the immunochemical diagnoses of COVID-19: firstly, detection of the antibodies specific to SARS-CoV-2 produced as the results of the disease and, sec- ondly, detection of the SARS-CoV-2 antigen in an immunoassay (37). Besides the immunochemical tests, genetic methods play a significant role (38-40).

A chemically isolated or manmade SARS-CoV-2 antigen can serve in various immunoassays for the recognition of anti-SARS$\mathrm{CoV}-2$ antibodies presented in the blood and confirming the COVID-19 by a feedback. The diagnosis based on anti - SARSCoV-2 antibodies is possible approximately a week after the first symptoms onset, when the antibodies are produced in sufficient quantity (41). Test like immunoblot analysis (42), chemiluminescence immunoassays $(43,44)$, enzyme immunoassays (45), standard enzyme-linked immunosorbent assay (ELISA) (46) are described and either currently available or under development. Though the tests based on the recognition of specific antibodies to SARS-CoV-2 can be adopted for the point-of-care conditions and can be easy and cheap, they are not reliable for the early diagnosis because of the delay between the infection starting and antibodies production by the patient's immune system. The peak of the most specific immunoglobulins of $\mathrm{G}$ isotype can be expected between $22-28$ days after the infection start (47). On the other hand, these tests can serve for a retrospective diagnosis and identification of people that can be resistant to the disease due to acquired immunity response.

Comparing to the antibodies testing, an assay of SARS-CoV-2 antigen can provide information about the COVID-19 before the onset of typical symptoms or in the time, when the symptoms start $(48,49)$. Antigens for the tests purpose are typically taken by nasopharyngeal swab, anterior nares swab $(50,51)$, saliva and saline gargle samples (52-54). N protein $(55,56)$, S protein (57-59) and $\mathrm{M}$ protein (60) are the most common targets for an antigen assay. A wide number of assays can be covered under the term antigen or antigenic tests and assays like ELISA (61) can be used for the antigen tests and chromatographic and mass spectrometry assays (62-65) are also suitable for the assay purpose; however, lateral flow tests (or lateral flow immunochromatographic assay or lateral flow immunochromatography) are relevant in the current clinical praxis of COVID-19 diagnosis (66). The lateral flow tests are also well suited for the point-of-care conditions. The currently available lateral flow tests are a simple analytical tool based on the migration of sample through a thin layer soaked with labelled antibodies or antigens and containing two zones with immobilized antibodies or antigens providing typical coloured lines (67-70). The principle can be described as follows. In one side of the tests, there is a spot where sample is injected. An analysed protein like 


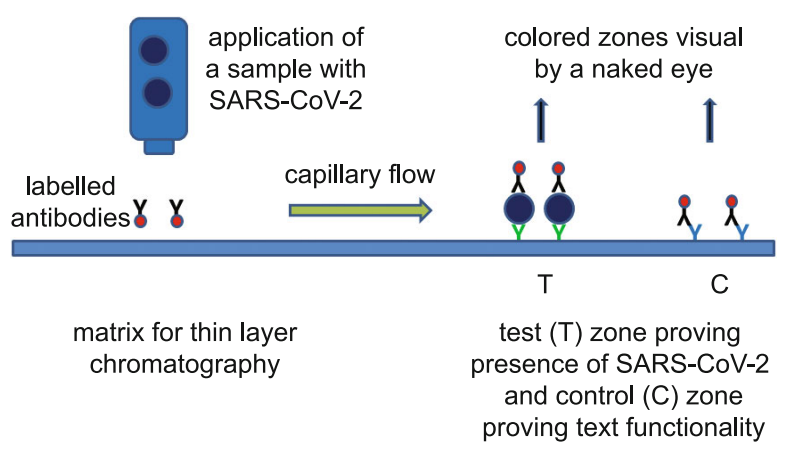

Fig. 1. General principle of the lateral flow test for SARS-CoV-2 antigen assay.

the $\mathrm{S}$ or $\mathrm{N}$ interacts with specific and labelled antibodies soaked into the matrix. The whole mixture migrates thorough the matrix by capillary flow up to the sites, where an antibody specific to the analysed proteins captures the complex protein-labelled antibody. Positive spot is formed by this way. The unreacted antibodies are caught by the immobilized anti-antibodies and a control spot is formed. Principle of the lateral flow test for SARS-CoV-2 antigen assay can be learned from the Figure 1 .

In the current market, there is a number of products working on the principle of lateral flow tests for SARS-CoV-2 antigen assay. An example of a test is depicted as Figure 2. These commercially available lateral flow tests represent the first line tools for COVID-19 diagnosis (71). Nasopharyngeal swab specimens are typically better (the results are more sensitive and accurate) for the assay purpose than the saliva samples (72). The commercial

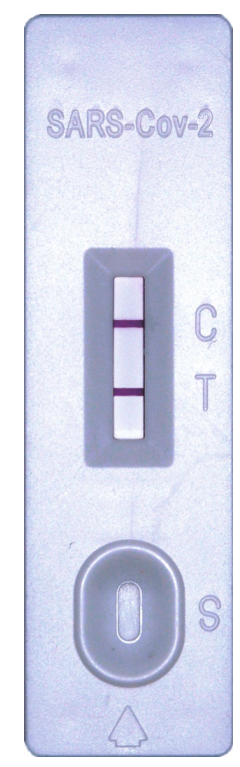

Fig. 2. An example of a commercial SARS-CoV-2 antigen assay test working on principle of lateral flow test; $S$ - site for specimen (extracted swab) application, $T$ - test site where a line is formed in the case of positive tests, $\mathrm{C}$ - site for control line. tests have a fluctuating quality depending on the materials used by the manufacturer, used type of antibody and coloured or fluorescent label. Sensitivity estimated by brand is between $66.0-93.8 \%$ of the currently available tests (73). In the study by Thakur and co-workers, there was conducted a diagnosis of 677 patients (74). The antigen tests exerted the positive predictive value equal to $96.6 \%$ and the negative predictive value $91.5 \%$. In another study, specificity $99.96 \%$ using a commercially available antigen tests were reached on the swab samples (75). The limit of detection of the tests should be taken into consideration, when a patient with an expected higher tolerability to the COVID-19 is diagnosed. In the work by Caputo and co-workers performed on 4266 samples, the limit of detection figured out was $222 \mathrm{pg}$ of SARS-CoV-2 in one millilitre of isolate suspension while lower concentrations did not prove coloured lines in the used standard antigen test (76).

Though an antigen test can be reliable as the first line diagnostic tool for COVID-19, the unambiguous confirmation of the disease is made by genetical tests like polymerase chain reaction (PCR) or by another genetic assay like loop-mediated isothermal amplification (LAMP). Regarding the PCR, real-time reverse transcription variant is the most common (77-81). The real time reverse transcription PCR exerts a good sensitivity and selectivity. For instance, Zhang and co-workers proved the sensitivity in the range 95.0-95.3\% and specificity $93.7-98.6 \%$ for PCR of housekeeping gene ribonuclease P/MRP subunit p30 and retrospectively re-analysed 1052 samples (82). PCR should be performed in the specialized labs and it is not suitable for the point-of-care testing; on the other hand, it represents a reliable tool for the diagnosis purposes. Reverse transcription LAMP is another method based on selective recognition of specific sequences in the genetic information and it has found an application in the COVID-19 diagnosis (83-86). Reverse transcription LAMP is a substantially simplified and more affordable genetic test compared to the PCR, it is also fully applicable for COVID-19 diagnosis and it can be also applied without an isolation of RNA from specimens (87). Though LAMP should be considered as a laboratory technique, further development can bring the point-of-care devices based on LAMP and applicable for COVID-19 diagnosis (88). The survey of basic tests and methods for molecular level COVID-19 diagnosis is depicted as Table 2.

As seen from the text above, antigen tests represent the first line diagnosis mean for COVID-19. Though they are not suitable for a replacement of the more accurate genetic tests like PCR, they are the only widely available diagnostic tool for revealing COVID-19 before the fatal symptoms onset and that is contemporary suitable for the point-of-care use. The currently available devices for SARS-CoV-2 antigen determination work on the principle of lateral flow tests.

\section{The next development in SARS-CoV-2 antigen assays}

Despite a good availability of SARS-CoV-2 antigen assays working on the principle of lateral flow tests, research on new means continues and some improved devices suitable for point-ofcare use can be expected in future. The development is founded on the implementation of new technologies and materials providing 
Tab. 2. Comparison of the basic tests for COVID-19 molecular level diagnosis.

\begin{tabular}{|c|c|c|c|c|c|}
\hline Type of test & Analyte & Sample & $\begin{array}{l}\text { Retrospective } \\
\text { diagnosis }\end{array}$ & $\begin{array}{c}\text { Plausible diagnosis } \\
\text { before symptoms } \\
\text { onset }\end{array}$ & $\begin{array}{l}\text { Suitability for } \\
\text { point-of-care } \\
\text { testing }\end{array}$ \\
\hline Antibody tests & $\begin{array}{l}\text { antibodies produced against } \\
\text { SARS-CoV-2 in the body }\end{array}$ & blood, plasma, serum & yes & no & yes \\
\hline $\begin{array}{l}\text { Antigen } \\
\text { (antigenic) tests }\end{array}$ & $\begin{array}{l}\text { SARS-CoV- } 2 \text { antigen structures } \\
\text { like } \mathrm{N}, \mathrm{S} \text { or } \mathrm{M} \text { proteins }\end{array}$ & $\begin{array}{l}\text { naso-pharyngeal swab, anterior } \\
\text { nares swab, saliva and saline } \\
\text { gargle samples }\end{array}$ & no & yes & yes \\
\hline $\begin{array}{l}\text { Genetic tests } \\
\text { (PCR, LAMP) }\end{array}$ & $\begin{array}{l}\text { genetic information of } \\
\text { SARS-CoV-2 }\end{array}$ & $\begin{array}{l}\text { naso-pharyngeal swab, anterior } \\
\text { nares swab, saliva and saline } \\
\text { gargle samples }\end{array}$ & no & yes & no \\
\hline
\end{tabular}

better specifications of the assays. New nanomaterials (89-91), molecules with an improved recognition capability - biorecognition elements like new type of antibodies or aptamers (92-94) and devices suitable for the point-of-care bioassays combining the biorecognition elements with a sensor platform, biosensors, and similar point-of-care diagnostic means (95-102) are progressively evolving in the COVID-19 diagnostics.

In the work by Azad and co-workers, a biosensor was proposed, where nanoluciferase interacts with $\mathrm{S} 1$ subunit of S protein and the final conjugate exert bioluminescent reaction that is optically or visually detectable (103). In another paper, a surface enhanced Raman spectroscopy biosensor based on plates covered with nanostructured needles from gold and covered with ACE2 was manufactured (104). The biosensor exerted the limit of detection 80 copies of SARS-CoV-2 per one millilitre and the assay time 5 minutes. The surface enhanced Raman spectroscopy was also chosen by Gao and co-workers for COVID-19 diagnosis (105).
The researchers prepared a biosensor based on gold nanoparticles with immobilized DNA that selectively interacts with RNA of SARS-CoV-2. The interaction was detectable by colorimetry, fluorimetry and surface enhanced Raman spectroscopy as well and the limit of detection $160 \mathrm{fmol} / 1$ for absorbance assay, $29 \mathrm{fmol} / 1$ for fluorescence assay and $395 \mathrm{fmol} / 1$ for surface enhanced Raman spectroscopy was achieved. Another colorimetric assay was developed by Kim and co-workers (106). The researchers used the principle of lateral flow immunoassay (lateral flow test) where the recognition of $\mathrm{N}$ protein was made by specific single-chain variable fragment-crystallizable fragment fusion antibodies specific against $\mathrm{N}$ protein and cellulose nanobeads as a label. The assay provided the limit of detection $2 \mathrm{ng}$ of antigen. In another study, an electrochemiluminescence biosensor was targeted to the RNAdependent RNA polymerase gene of SARS-CoV-2 (107). The biosensor contained electrode covered with DNA tetrahedron and single stranded DNA labelled with tris(bipyridine)ruthenium (II)

Tab. 3. Survey of newly developed antigenic tests for COVID-19 diagnosis.

\begin{tabular}{|c|c|c|c|}
\hline Type of assay & Description & Specifications & References \\
\hline $\begin{array}{l}\text { surface enhanced } \\
\text { Raman spectroscopy }\end{array}$ & $\begin{array}{l}\text { biosensor is based on plates covered with gold nano } \\
\text { needles further modified with ACE2, the surface interacts } \\
\text { with SARS-CoV-2 S antigen from sample, the interaction } \\
\text { is recorder by Raman spectroscopy }\end{array}$ & $\begin{array}{l}\text { limit of detection } 80 \text { copies of SARS- } \\
\text { CoV-2 per one millilitre, assay time } 5 \\
\text { minutes }\end{array}$ & $(104)$ \\
\hline $\begin{array}{l}\text { colorimetry, fluorimetry, } \\
\text { surface enhanced Raman } \\
\text { spectroscopy }\end{array}$ & $\begin{array}{l}\text { gold nanoparticles covered with specific DNA reacted } \\
\text { with RNA from SARS-CoV-2 providing detectable signal }\end{array}$ & $\begin{array}{l}\text { limit of detection } 160 \mathrm{fmol} / 1 \text { for } \\
\text { absorbance assay, } 29 \mathrm{fmol} / 1 \text { for } \\
\text { fluorescence assay and } 395 \mathrm{fmol} / 1 \text { for } \\
\text { surface enhanced Raman spectroscopy }\end{array}$ & $(105)$ \\
\hline $\begin{array}{l}\text { lateral flow immunoassay } \\
\text { (lateral flow test) }\end{array}$ & $\begin{array}{l}\text { common lateral flow immunoassay where cellulose nanobeads } \\
\text { covered with anti N protein antibodies were used }\end{array}$ & limit of detection $2 \mathrm{ng}$ of antigen & $(106)$ \\
\hline electrochemiluminiscence & $\begin{array}{l}\text { biosensor with DNA tetrahedron interacted with single } \\
\text { stranded DNA labelled with tris(bipyridine)ruthenium(II) } \\
\text { chloride and the target RNA-dependent RNA polymerase } \\
\text { gene of SARS-CoV-2, the formation of complex was } \\
\text { accompanied with measurable electrochemiluminescence }\end{array}$ & $\begin{array}{l}\text { limit of detection } 2.67 \mathrm{fmol} / 1 \text { of RNA- } \\
\text { dependent RNA polymerase gene }\end{array}$ & $(107)$ \\
\hline potentiometry & $\begin{array}{l}\text { field effect transistor with single-walled carbon nanotubes } \\
\text { further modified by antibody anti S or N protein providing } \\
\text { interaction with SARS-CoV-2 from a sample, the interaction } \\
\text { is measured potentiometrically }\end{array}$ & $\begin{array}{l}\text { limit of detection } 0.55 \mathrm{mg} / \mathrm{ml} \text { for } \mathrm{N} \\
\text { protein and } 0.016 \mathrm{fg} / \mathrm{ml} \text { for } \mathrm{S} \text { protein }\end{array}$ & $(108)$ \\
\hline potentiometry & $\begin{array}{l}\text { field effect transistor modified with graphene coated by } \\
\text { specific antibody specific to S protein of SARS-CoV-2, } \\
\text { the interaction is measured potentiometrically }\end{array}$ & $\begin{array}{l}\text { limit of detection } 16 \text { plaque forming } \\
\text { units per millilitre in cultured medium } \\
\text { analyzed and } 242 \text { copies per millilitre } \\
\text { for clinical swab samples }\end{array}$ & (109) \\
\hline
\end{tabular}


chloride was also used for the recognition of the target sequence of SARS-CoV-2, the formation of complex was accompanied with measurable electrochemiluminescence that was suitable for reaching of the limit of detection $2.67 \mathrm{fmol} / 1$ of RNA-dependent RNA polymerase gene from SARS-CoV-2.

Semiconductive sensors can play a role in the detection of antigens from SARS-CoV-2. Such concept was for instance proposed by Shao and co-workers (108). The authors used a field effect transistor as a platform and modified it with single-walled carbon nanotubes further covered by an antibody specific to $\mathrm{S}$ or $\mathrm{N}$ protein. Interaction with SARS-CoV-2 was potentiometrically determined and the $\mathrm{S}$ protein was analysed with the limit of detection $0.55 \mathrm{mg} / \mathrm{ml}$ while the $\mathrm{S}$ protein with the limit of detection 0.016 $\mathrm{fg} / \mathrm{ml}$. A potentiometric filed effect transistor founded biosensor was also described in the work by Seo and co-workers (109). The biosensor contained a field effect transistor modified with graphene coated by specific antibody specific to S protein of SARS-CoV-2. The biosensor potentiometrically determined SARS-CoV-2 with the limit of detection 16 plaque forming units per millilitre, when the cultured medium was analysed and 242 copies per millilitre for clinical swab samples (106). The Survey of the newly searched devices described in this text is presented in Table 3 .

\section{Conclusions}

Small hand-held assays applicable in the point-of-care conditions for diagnosis of pathological states are the means of a growing interest and these means are gradually introduced into the market. The diagnosis of COVID- 19 is not an exception and the development relates to these means as well. In the current time, the diagnosis of COVID-19 based on the commercial lateral flow tests are widely available and they fully meet the requirements placed on the point-of-care device. Though the antigen tests are less sensitive than the more advanced genetic assays like PCR, they are highly competitive to the other methods by price and overall simplicity. It is expected that the further improvements and application of advanced materials will further increase their competitivity to the other types of SARS-CoV-2 assay. This work can be concluded by a statement that antigen tests are substantial tool for control of COVID-19 with no fully applicable commercial alternative for the point-of-care conditions.

\section{References}

1. Rehman H, Ahmad MI. Covid-19: A wreak havoc across the globe. Arch Physiol Biochem 2020; DOI: 10.1080/13813455.2020.1797105.

2. Senapati A, Rana S, Das T, Chattopadhyay J. Impact of intervention on the spread of covid-19 in india: A model based study. J Theor Biol 2021; 13 (110711): 110711.

3. Post L, Boctor MJ, Issa TZ et al. Canada sars-cov-2 surveillance system: Longitudinal trend analysis. JMIR Public Health Surveill 2021; 9 (10): 25753.

4. Mutanga SS, Ngungu M, Tshililo FP, Kaggwa M. Systems dynamics approach for modelling south africa's response to covid-19: A "what if" scenario. J Public Health Res 2021; 10 (1): 1897.
5. Wang C, Xiao X, Feng $\mathbf{H}$ et al. Ongoing covid-19 pandemic: A concise but updated comprehensive review. Curr Microbiol 2021; 13: $1-12$.

6. Gedikli MA, Tuzun B, Aktas A, Sayin K, Ataseven H. Are clarithromycin, azithromycin and their analogues effective in the treatment of covid19? Bratisl Lek Listy 2021; 122 (2): 101-110.

7. Leneva IA, Pshenichnaya NY, Bulgakova VA. Umifenovir and coronavirus infections: A review of research results and clinical practice. Ter Arkhiv 2020; 92 (11): 91-97.

8. De P, Chakraborty I, Karna B, Mazumder N. Brief review on repurposed drugs and vaccines for possible treatment of covid-19. Eur J Pharmacol 2021; 898: 173977.

9. Benmansour NC, Carvelli J, Vivier E. Complement cascade in severe forms of covid-19: Recent advances in therapy. Eur J Immunol 2021; DOI: 10.1002/eji.202048959.

10. Li QY, Zhao CY. A review of the current status of clinical management of covid-19 in the elderly. Med Sci Monitor 2021; 27: e930278.

11. Nasonov E, Samsonov M. The role of interleukin 6 inhibitors in therapy of severe covid-19. Biomed Pharmacother 2020; 131: 110698.

12. Kabir MA, Ahmed R, Iqbal SMA et al. Diagnosis for covid-19: Current status and future prospects. Expert Rev Mol Diagn 2021; DOI: 10.1080/14737159.2021.1894930.

13. Hellou MM, Gorska A, Mazzaferri F et al. Nucleic acid amplification tests on respiratory samples for the diagnosis of coronavirus infections: A systematic review and meta-analysis. Clin Microbiol Infect 2021; 27 (3): 341-351.

14. Nascimento JAC, Santos AM, Oliveira AMS et al. Trends in merscov, sars-cov, and sars-cov-2 (covid-19) diagnosis strategies: A patent review. Front Public Health 2020; 8: 563095.

15. Stern RA, Koutrakis P, Martins MAG et al. Characterization of hospital airborne sars-cov-2. Respir Res 2021; 22 (1): 73.

16. Bhavsar AA. The spread of macroscopic droplets from a simulated cough with and without the use of masks or barriers. PLoS One 2021; 16 (5): $\mathrm{e} 0250275$.

17. Issakhov $A$, Zhandaulet $Y$, Omarova $P$, Alimbek A, Borsikbayeva A, Mustafayeva A. A numerical assessment of social distancing of preventing airborne transmission of covid-19 during different breathing and coughing processes. Sci Rep 2021; 11 (1): 9412.

18. Yang J, Zhang Z, Yang $\mathbf{F}$ et al. Computational design and modeling of nanobodies toward sars-cov-2 receptor binding domain. Chem Biol Drug Des 2021; 24 (10): 13847.

19. Ortega JT, Pujol FH, Jastrzebska B, Rangel HR. Mutations in the sars-cov-2 spike protein modulate the virus affinity to the human ace2 receptor, an in silico analysis. Excli J 2021; 20: 585-600.

20. Sarode GS, Sarode SC, Gadbail AR, Gondivkar S, Sharma NK, Patil S. Angiotensin-converting enzyme 2 specific cell subset identification in oral tissues: A need of the hour in covid-19 research. J Contemp Dent Pract 2020; 21 (12): 1305-1306.

21. Gheblawi M, Wang K, Viveiros A et al. Angiotensin-converting enzyme 2: Sars-cov-2 receptor and regulator of the renin-angiotensin system: Celebrating the 20th anniversary of the discovery of ace2. Circ Res 2020; 126 (10): 1456-1474.

22. Taribagil P, Creer D, Tahir H. Long covid' syndrome. BMJ Case Rep 2021; 14 (4): 2020-241485. 
23. Sanku K, Siddiqui A, Paul V, Moeez A. An unusual case of gastrointestinal bleeding in a patient with covid-19. Cureus 2021; 13 (3): e13901.

24. Wiegele PN, Kabar I, Kerschke $L$ et al. Symptom diary-based analysis of disease course among patients with mild coronavirus disease, germany, 2020. Emerg Infect Dis 2021; 27 (5): 1353-1361.

25. Yildiz E, Balci A, Selendili O, Kuzu S. Olfactory cleft opacification in covid-19 related smell loss: Ct findings and correlation with objective testing. Ear Nose Throat J 2021; 21 (1455613211011285): 01455613211011285 .

26. Gonzalez C, Garcia-Huidobro FG, Lagos AE et al. Prospective assessment of smell and taste impairment in a south-american coronavirus disease 2019 (covid-19) cohort: Association with the need for hospitalization and reversibility of dysfunction. Int Forum Allergy Rhinol 2021; DOI: 10.1002/alr.22798.

27. Batterham PJ, Calear AL, McCallum SM et al. Trajectories of depression and anxiety symptoms during the covid-19 pandemic in a representative australian adult cohort. Med J Aust 2021; 26 (10): 51043.

28. Tu TM, Seet CYH, Koh JS et al. Acute ischemic stroke during the convalescent phase of asymptomatic covid-2019 infection in men. JAMA Netw Open 2021; 4 (4): e217498.

29. de Marcellus C, Dupic L, Roux CJ et al. Case report: Cerebrovascular events associated with bacterial and sars-cov- 2 infections in an adolescent. Front Neurol 2021; 12: 606617.

30. Bar-On YM, Flamholz A, Phillips R, Milo R. Sars-cov-2 (covid-19) by the numbers. Elife 2020; 9: e57309.

31. Schoeman D, Fielding BC. Coronavirus envelope protein: Current knowledge. Virol J 2019; 16: 69.

32. Cazares LH, Chaerkady R, Weng SHS et al. Development of a parallel reaction monitoring mass spectrometry assay for the detection of sars-cov-2 spike glycoprotein and nucleoprotein. Anal Chem 2020; 92 (20): 13813-13821.

33. Thomas $\mathrm{S}$. The structure of the membrane protein of sars-cov- 2 resembles the sugar transporter semisweet. Pathog Immun 2020; 5 (1): 342-363.

34. Mehdipour AR, Hummer G. Dual nature of human ace2 glycosylation in binding to sars-cov-2 spike. Proc Natl Acad Sci USA 2021; 118 (19): 2100425118.

35. Verkhivker GM, Agajanian S, Oztas DY, Gupta G. Comparative perturbation-based modeling of the sars-cov-2 spike protein binding with host receptor and neutralizing antibodies: Structurally adaptable allosteric communication hotspots define spike sites targeted by global circulating mutations. Biochemistry 2021; 26 (10).

36. Ghorbani A, Samarfard S, Eskandarzade $\mathrm{N}$ et al. Comparative phylogenetic analysis of sars-cov-2 spike protein-possibility effect on virus spillover. Brief Bioinform 2021; 22 (10).

37. Pohanka M. Covid-19 molecular level laboratory diagnoses. Bratisl Lek Listy 2021; 122 (1): 11-17.

38. Kumar KSR, Mufti SS, Sarathy V, Hazarika D, Naik R. An update on advances in covid-19 laboratory diagnosis and testing guidelines in india. Front Public Health 2021; 9: 568603.

39. Goudouris ES. Laboratory diagnosis of covid-19. J Pediatr 2021; 97 (1): 7-12.

40. Farasani A. Genetic analysis of the 2019 coronavirus pandemic with from real-time reverse transcriptase polymerase chain reaction. Saudi J Biol Sci 2021; 28 (1): 911-916.
41. Deeks JJ, Dinnes J, Takwoingi Y et al. Antibody tests for identification of current and past infection with sars-cov-2. Cochrane Database Syst Rev 2020; 6 (6): CD013652.

42. Meinberger D, Koch M, Roth A et al. Analysis of igm, iga, and igg isotype antibodies directed against sars-cov-2 spike glycoprotein and orf8 in the course of covid-19. Sci Rep 2021; 11 (1): 021-88356.

43. Villalta D, Martelli P, Moratto A et al. Diagnostic performance of an automated chemiluminescence immunoassay for sars-cov-2 igg and igm antibodies detection: A real life experience. Pract Lab Med 2021; 25 (10): 19.

44. Nah EH, Cho S, Park H, Hwang I, Cho HI. Nationwide seroprevalence of antibodies to sars-cov-2 in asymptomatic population in south korea: A cross-sectional study. BMJ Open 2021; 11 (4): e049837.

45. Jalkanen P, Pasternack A, Maljanen $S$ et al. A combination of $n$ and $s$ antigens with iga and igg measurement strengthens the accuracy of sarscov-2 serodiagnostics. J Infect Dis 2021; 27 (10): jiab222.

46. Zonneveld R, Jurriaans $S$, van Gool $T$ et al. Head-to-head validation of six immunoassays for sars-cov-2 in hospitalized patients. J Clin Virol 2021; 139 (104821): 104821.

47. Guo L, Wang YM, Kang L et al. Cross-reactive antibody against human coronavirus oc43 spike protein correlates with disease severity in covid-19 patients: A retrospective study. Emerg Microbes Infect 2021; 10 (1): 664-676.

48. Ristic M, Nikolic N, Cabarkapa V, Turkulov V, Petrovic V. Validation of the standard q covid-19 antigen test in vojvodina, serbia. PLoS One 2021; 16 (2): e0247606.

49. Candel FJ, Barreiro P, San Roman J et al. Recommendations for use of antigenic tests in the diagnosis of acute sars-cov-2 infection in the second pandemic wave: Attitude in different clinical settings. Rev Esp Quim 2020; 33 (6): 466-484.

50. Siegler AJ, Sullivan PS, Sanchez T et al. Protocol for a national probability survey using home specimen collection methods to assess prevalence and incidence of sars-cov-2 infection and antibody response. Ann Epidemiol 2020; 49: 50-60.

51. Carmagnola D, Henin D, Pellegrini G et al. Diagnostic testing for sars-cov-2: State of the art and perspectives of molecular salivary testing. Dent Cadmos 2021; 89 (4): 264-276.

52. Goldfarb DM, Tilley P, Al-Rawahi GN et al. Self-collected saline gargle samples as an alternative to health care worker-collected nasopharyngeal swabs for covid-19 diagnosis in outpatients. J Clin Microbiol 2021; 59 (4): e02427-02420.

53. Amendola A, Sberna G, Lalle $\mathbf{E}$ et al. Saliva is a valid alternative to nasopharyngeal swab in chemiluminescence-based assay for detection of sars-cov-2 antigen. J Clin Med 2021; 10 (7): 1471.

54. Bohn MK, Lippi G, Horvath AR et al. Ifcc interim guidelines on rapid point-of-care antigen testing for sars-cov-2 detection in asymptomatic and symptomatic individuals. Clin Chem Lab Med 2021; 27 (10): 2021-0455.

55. Barlev-Gross M, Weiss $\mathbf{S}$, Ben-Shmuel A et al. Spike vs nucleocapsid sars-cov-2 antigen detection: Application in nasopharyngeal swab specimens. Anal Bioanal Chem DOI: 10.1007/s00216-021-03298-4.

56. Shan D, Johnson JM, Fernandes SC et al. N-protein presents early in blood, dried blood and saliva during asymptomatic and symptomatic sars-cov-2 infection. Nat Commun 2021; 12 (1): 1931.

57. Marien J, Ceulemans A, Michiels J et al. Evaluating sars-cov-2 spike and nucleocapsid proteins as targets for antibody detection in severe and mild covid-19 cases using a luminex bead-based assay. J Virol Methods 2021; 288: 114025 . 
58. Herrera NG, Morano NC, Celikgil A et al. Characterization of the sars-cov-2 s protein: Biophysical, biochemical, structural, and antigenic analysis. ACS Omega 2021; 6 (1): 85-102.

59. Rodriguez-Moncayo R, Cedillo-Alcantar DF, Guevara-Pantoja PE et al. A high-throughput multiplexed microfluidic device for covid-19 serology assays. Lab Chip 2021; 21 (1): 93-104.

60. Saadi J, Oueslati S, Bellanger $L$ et al. Quantitative assessment of sars-cov-2 virus in nasopharyngeal swabs stored in transport medium by a straightforward lc-ms/ms assay targeting nucleocapsid, membrane, and spike proteins. J Proteome Res 2021; 20 (2): 1434-1443.

61. Di Domenico M, De Rosa A, Boccellino M. Detection of sars-cov-2 proteins using an elisa test. Diagnostics 2021; 11 (4): 698.

62. Rybicka M, Milosz E, Bielawski KP. Superiority of maldi-tof mass spectrometry over real-time pcr for sars-cov-2 rna detection. Viruses 2021; 13 (5): 730

63. Hatakeyama D, Masuda T, Miki R, Ohtsuki S, Kuzuhara T. Invitro acetylation of sars-cov and sars-cov-2 nucleocapsid proteins by human pcaf and gen5. Biochem Biophys Res Commun 2021; 557: 273-279.

64. Scholle MD, Liu C, Deval J, Gurard-Levin ZA. Label-free screening of sars-cov-2 nsp14 exonuclease activity using samdi mass spectrometry. SLAS Discov 2021; 17 (24725552211008854): 24725552211008854.

65. Deulofeu M, García-Cuesta E, Peña-Méndez EM et al. Detection of sars-cov-2 infection in human nasopharyngeal samples by combining maldi-tof ms and artificial intelligence. Front Med 2021; 8 (661358).

66. Blairon L, Wilmet A, Beukinga I, Tre-Hardy M. Implementation of rapid sars-cov-2 antigenic testing in a laboratory without access to molecular methods: Experiences of a general hospital. J Clin Virol 2020; 129: 104472.

67. Urusov AE, Zherdev AV, Dzantiev BB. Towards lateral flow quantitative assays: Detection approaches. Biosensors 2019; 9 (3): 89.

68. Pohanka M. Point-of-care diagnoses and assays based on lateral flow test. Int J Anal Chem 2021; 2021: 6685619.

69. Andryukov BG, Lyapun IN, Bynina MP, Matosova EV. Simplified formats of modern biosensors: 60 years of using immunochromatographic test systems in laboratory diagnostics. Klin Lab Diagn 2020; 65 (10): 611-618.

70. Andryukov BG. Six decades of lateral flow immunoassay: From determining metabolic markers to diagnosing covid-19. AIMS Microbiol 2020; 6 (3): 280-304

71. Yin N, Debuysschere C, Decroly M et al. Sars-cov-2 diagnostic tests: Algorithm and field evaluation from the near patient testing to the automated diagnostic platform. Front Med 2021; 8 (650581).

72. Uwamino Y, Nagata M, Aoki W et al. Accuracy of rapid antigen detection test for nasopharyngeal swab specimens and saliva samples in comparison with rt-pcr and viral culture for sars-cov-2 detection. J Infect Chemother 2021; 17 (21): S1341-1321X(1321)00117-00113.

73. Bruzzone B, De Pace V, Caligiuri P et al. Comparative diagnostic performance of different rapid antigen detection tests for covid-19 in the real-world hospital setting. Int J Infect Dis 2021; 27 (21): 00384-00382.

74. Thakur P, Saxena S, Manchanda V, Rana N, Goel R, Arora R. Utility of antigen-based rapid diagnostic test for detection of sars-cov-2 virus in routine hospital settings. Lab Med 2021; 30 (10): 1mab033.

75. Muhi S, Tayler N, Hoang $T$ et al. Multi-site assessment of rapid, point-of-care antigen testing for the diagnosis of sars-cov- 2 infection in a low-prevalence setting: A validation and implementation study. Lancet Reg Health West Pac 2021; 9 (100115): 2.
76. Caputo V, Bax C, Colantoni $L$ et al. Comparative analysis of antigen and molecular tests for the detection of sars-cov-2 and related variants: A study on 4266 samples. Int J Infect Dis 2021; 17 (21): S1201-9712(1221)00359-00353.

77. Parra-Ortega I, Vilchis-Ordoñez A, López-Martínez B, AngelesFloriano T. Analytical recommendations for sars-cov-2 identification by rt-pcr in pediatric patients. Bol Med Hosp Infant Mex 2021; 3 (10): 20000210

78. Bedolla-Barajas M, Morales-Romero J, Bedolla-Pulido TR et al. Low prevalence of asthma in mexican children and adults with a positive rtrt-pcr test for sars-cov-2: A cross-sectional study during the 2020 pandemic. Allergol Immunopathol 2021; 49 (3): 1-7.

79. Onyilagha C, Mistry H, Marszal $P$ et al. Evaluation of mobile realtime polymerase chain reaction tests for the detection of severe acute respiratory syndrome coronavirus 2. Sci Rep 2021; 11 (1): 021-88625.

80. Peña M, Ampuero M, Garcés $C$ et al. Performance of sars-cov- 2 rapid antigen test compared with real-time rt-per in asymptomatic individuals. Int J Infect Dis 2021; 1 (21): 00399-00394.

81. Peltan ID, Beesley SJ, Webb BJ et al. Evaluation of potential covid-19 recurrence in patients with late repeat positive sars-cov-2 testing. PLoS One 2021; 16 (5): e0251214.

82. Zhang YF, Wang CT, Han MF et al. Discrimination of false negative results in rt-pcr detection of sars-cov-2 rnas in clinical specimens by using an internal reference. Virol Sin 2020; 35 (6): 758-767.

83. Day AS, Ulep TH, Safavinia B et al. Emulsion-based isothermal nucleic acid amplification for rapid sars-cov-2 detection via angle-dependent light scatter analysis. Biosens Bioelectron 2021; 179: 113099.

84. Reynes B, Serra F, Palou A. Rapid visual detection of sars-cov-2 by colorimetric loop-mediated isothermal amplification. Biotechniques 2021; DOI: $10.2144 / \mathrm{btn}-2020-0159$.

85. Diego JGB, Fernandez-Soto P, Dominguez-Gil M, Belhassen-Garcia M, Bellido JLM, Muro A. A simple, affordable, rapid, stabilized, colorimetric, versatile rt-lamp assay to detect sars-cov-2. Diagnostics 2021; 11 (3): 438.

86. Chan SK, Du PY, Ignacio C, Mehta S, Newton IG, Steinmetz NF. Virus-like particles as positive controls for covid-19 rt-lamp diagnostic assays. Biomacromolecules 2021; 22 (3): 1231-1243.

87. Garcia-Venzor A, Rueda-Zarazua B, Marquez-Garcia E et al. Sars-cov-2 direct detection without rna isolation with loop-mediated isothermal amplification (lamp) and crispr-cas12. Front Med 2021; 8: 627679 .

88. Moehling TJ, Choi G, Dugan LC, Salit M, Meagher RJ. Lamp diagnostics at the point-of-care: Emerging trends and perspectives for the developer community. Expert Rev Mol Diagn 2021; 21 (1): 43-61.

89. Tharayil A, Rajakumari R, Kumar A, Choudhary MD, Palit P, Thomas S. New insights into application of nanoparticles in the diagnosis and screening of novel coronavirus (sars-cov-2). Emerg Mater 2021; DOI: $10.1007 / \mathrm{s} 42247-021-00182-w$.

90. Sheervalilou R, Shirvaliloo M, Sargazi S et al. Application of nanobiotechnology for early diagnosis of sars-cov-2 infection in the covid-19 pandemic. Appl Microbiol Biotechnol 2021; 105 (7): 2615-2624.

91. Chauhan DS, Prasad R, Srivastava R, Jaggi M, Chauhan SC, Yallapu MM. Comprehensive review on current interventions, diagnostics, and nanotechnology perspectives against sars-cov-2. Bioconjugate Chem 2020; 31 (9): 2021-2045. 
763-770

92. Limsakul P, Charupanit K, Moonla C, Jeerapan I. Advances in emergent biological recognition elements and bioelectronics for diagnosing covid-19. Emerg Mater 2021; DOI: 10.1007/s42247-021-00175-9.

93. Samson R, Navale GR, Dharne MS. Biosensors: Frontiers in rapid detection of covid-19. 3 Biotech 2020; 10 (9): 385.

94. Ekrami E, Pouresmaieli M, Barati F et al. Potential diagnostic systems for coronavirus detection: A critical review. Biol Proced Online 2020; 22 (1): 21.

95. Abid SA, Muneer AA, Al-Kadmy IMS et al. Biosensors as a future diagnostic approach for covid-19. Life Sci 2021; 273: 119117.

96. Singh S, Kumar V, Kapoor D et al. Detection and disinfection of covid-19 virus in wastewater. Environ Chem Lett 2021; DOI: 10.1007/ s10311-021-01202-1.

97. Kevadiya BD, Machhi J, Herskovitz J et al. Diagnostics for sarscov-2 infections. Nat Mater 2021; DOI: 10.1038/s41563-020-00906-z.

98. Teklemariam AD, Samaddar M, Alharbi MG, Al-Hindi RR, Bhunia AK. Biosensor and molecular-based methods for the detection of human coronaviruses: A review. Mol Cell Probes 2020; 54: 101662.

99. Taha BA, Al Mashhadany Y, Mokhtar MHH, Bin Zan MSD, Arsad N. An analysis review of detection coronavirus disease 2019 (covid-19) based on biosensor application. Sensors 2020; 20 (23): 6764.

100. Parihar A, Ranjan P, Sanghi SK, Srivastava AK, Khan R. Point-ofcare biosensor-based diagnosis of covid-19 holds promise to combat current and future pandemics. ACS Appl Bio Mater 2020; 3 (11): 7326-7343.

101. Yadav S, Sadique MA, Ranjan $P$ et al. Sers based lateral flow immunoassay for point-of-care detection of sars-cov-2 in clinical samples. ACS Appl Bio Mater 2021; 4 (4): 2974-2995.
102. Ke GJ, Su DK, Li Y et al. An accurate, high-speed, portable bifunctional electrical detector for covid-19. Sci China-Mater 2021; 64 (3): 739-747.

103. Azad T, Singaravelu R, Brown EEF et al. Sars-cov-2 s1 nanobit: A nanoluciferase complementation-based biosensor to rapidly probe sars-cov-2 receptor recognition. Biosens Bioelectron 2021; 180: 113122.

104. Yang Y, Peng YS, Lin CL et al. Human ace2-functionalized gold "virus-trap" nanostructures for accurate capture of sars-cov-2 and singlevirus sers detection. Nano-Micro Lett 2021; 13 (1): 109.

105. Gao YK, Han YK, Wang $C$ et al. Rapid and sensitive triple-mode detection of causative sars-cov-2 virus speci fi c genes through interaction between genes and nanoparticles. Anal Chim Acta 2021; 1154: 338330.

106. Kim HY, Lee JH, Kim MJ et al. Development of a sars-cov-2-specific biosensor for antigen detection using scfv-fc fusion proteins. Biosens Bioelectron 2021; 175: 112868 .

107. Fan ZQ, Yao B, Ding YD, Zhao J, Xie MH, Zhang K. Entropydriven amplified electrochemiluminescence biosensor for rdrp gene of sarscov-2 detection with self-assembled DNA tetrahedron scaffolds. Biosens Bioelectron 2021; 178: 113015.

108. Shao WT, Shurin MR, Wheeler SE, He XY, Star A. Rapid detection of sars-cov-2 antigens using high-purity semiconducting single-walled carbon nanotube-based field-effect transistors. ACS Appl Mater Interfaces 2021; 13 (8): 10321-10327.

109. Seo G, Lee G, Kim MJ et al. Rapid detection of covid-19 causative virus (sars-cov-2) in human nasopharyngeal swab specimens using fieldeffect transistor-based biosensor. ACS Nano 2020; 14 (4): 5135-5142.

Received May 8, 2021. Accepted May 18, 2021. 